\title{
AEROSTATIC AND AERODYNAMIC MODULES OF A HYBRID BUOYANT AIRCRAFT: AN ANALYTICAL APPROACH
}

\author{
AnWar U. Haque, Waqar Asrar, Ashraf A. Omar, Erwin Sulaeman and \\ MOHAMED J.S. ALI \\ Department of Mechanical Engineering, International Islamic University Malaysia, \\ Jalan Gombak, 53100, Kuala Lumpur, Malaysia. \\ waqar@iium.edu.my
}

(Received 29 November 2014; accepted 25 February 2015; published on line 29 May 2015)

\begin{abstract}
An analytical approach is essential for the estimation of the requirements of aerodynamic and aerostatic lift for a hybrid buoyant aircraft. Such aircraft have two different modules to balance the weight of aircraft; aerostatic module and aerodynamic module. Both these modules are to be treated separately for estimation of the mass budget of propulsion systems and required power. In the present work, existing relationships of aircraft and airship are reviewed for its further application for these modules. Limitations of such relationships are also discussed and they provide a starting point for better understanding of design methodology of such aircraft.
\end{abstract}

ABSTRAK: Pendekatan beranalisis penting dalam perkiraan keperluan aerodinamik dan daya angkat aerostatik bagi sesebuah pesawat hibrid timbulan. Pesawat ini mempunyai dua modul berbeza untuk mengimbang berat pesawat; modul aerostatik dan aerodinamik. Kedua-dua modul ini perlu dikaji secara berasingan untuk perkiraan jisim anggaran sistem dorongan dan kuasa yang diperlukan. Buat masa ini, hubungan yang sedia ada antara pesawat dan kapal udara dikaji semula untuk aplikasi seterusnya bagi kedua-dua modul ini. Kekurangan hubungan ini juga diperbincangkan dan seterusnya merupakan titik permulaan untuk lebih memahami metadologi reka bentuk pesawat sedemikian.

KEYWORDS: aerostatic lift; aerodynamic lift; hybrid bouyant aircraft; drag polar.

\section{INTRODUCTION}

Knowledge regarding the aerodynamic characteristics of a flying vehicle forms the backbone in starting the conceptual design work. Aerodynamic data, especially the drag force predicted by experimental techniques can be highly reliable. Unfortunately the experimental data bank is limited for Hybrid Buoyant (HB) aircrafts, which differ with conventional airships in terms of generation of aerodynamic lift, takeoff and landing characteristics, as well as the structural anatomy. Airships usually fly at a constant altitude and use vertical takeoff and landing technology (VTOL) to avoid angle of attack. The concept of hybrid and its meanings for airships and aircrafts are not yet clear. This is because the term "hybrid" is not solely related with the lift generated by the hull body itself and/or by single or multiple wings, but it is also linked with the propulsion system used by them. Depending on the type of propulsion system, a general consensus does exist about various types of hybrid airships, but "there is no authoritative definition of it". Similar to an aircraft, a hybrid buoyant is a buoyant aerial vehicle in which the propulsion system is hybrid. A buoyant aircraft can take off and land either by using the landing gears or VTOL, or both. The exact estimation of lift by the hull is also challenging. Relative to 
the wing, the hull span will be quite small. As a result, the applicability of empirical relationships used for estimating the lift generated by the wing [1-3], becomes questionable as such relationships are derived for high aspect ratio tapered wings. [4] A good solution to this issue of lifting the fuselage, will be to carry out numerical flow simulations [5] to find out the value of total drag and lift force. However, numerical simulations take a long time and there is a need to look back at the existing analytical relationships of aircraft and airships for their utilization in the estimation of aerodynamic properties - hence the need to merge such existing relationships for aerostatic as well as aerodynamic modules of $\mathrm{HB}$ aircraft.

\section{MODULES OF A HYBRID BUOYANT AIRCRAFT}

In HB aircrafts, aerostatic lift is produced by the lifting gas which is stored in gas cells. The concept of gas cells comes from rigid airships in which several gas cells are arranged along the longitudinal axis of hull of airship which are free to expand and contract due to variation in atmospheric properties of air $[6,7]$. The hull's outer skin is made a certain fabric material, which requires an internal pressure to maintain its aerodynamic shape, especially when the lifting gas shrinks during the descent flight segment. The shape of the hull can be in the shape of an airfoil such that additional aerodynamic lift is generated by the hull from the beginning of ground roll in the take-off segment. Moreover, similar to a winged airship; a wing can be attached with such a hull to generate partial lift. In this way; there are two different modules, which are to be treated separately to obtain information about the aerostatic as well as aerodynamic behavior of such aircrafts. In the following sections, these modules are discussed focusing on the further utilization of such analytical relationships.

\subsection{Aerostatic Module}

In airships, aerostatic lift comes from lifting gas [8], aerodynamic lift arises from the contour of hull at certain angle of attack and power static lift originates from the propellers of STOL engines. Aerostatic lift, which remains constant till pressure height[9], is estimated for a given volume of gas cell inside the envelope by applying Archimedes principle [10] which is expressed as Eq. (1):

$$
L_{\text {buoy }}=\operatorname{Vol}\left(\rho_{A}-\rho_{G}\right) g
$$

The densities of the air $\rho_{A}$ and gas $\rho_{G}$ are defined (Eq. 2) according to Clapeyron equation for ideal gas [7]; in which $P$ andTare absolute pressure and temperature of air/gas. As per airship's design standard [11], thelifting capacity of helium gas is about $1.05 \mathrm{~kg} / \mathrm{m}^{3}$, against its density equal to $0.1785 \mathrm{~kg} / \mathrm{m}^{3}$ with $96 \%$ purity at sea level condition.

$$
\rho=\frac{P}{R T}
$$

Forlifting gas cells, required volume, shape of individual gas cell, properties of material and its allocated space inside the hull are required. For non-rigid airships and blimps, shape of the outer contour is maintained by keeping the internal pressure in the envelope for maintaining the shape [10]. But the volume of the lifting gas is dependent on altitude and temperature of lifting gas itself. For example, superheating, due to sun heat will cause a change in buoyant lift $\Delta L_{\text {buoy }}$ and according to ideal gas law, change in volume can be represented as Eq. (3) [12]: 


$$
\Delta L_{\text {buoy }}=\frac{G_{a} P V_{o l} \Delta T_{g}}{T_{g}^{2}}
$$

Where $G_{a}$ is equal to $\frac{\rho_{a} T_{a}}{P_{a}}$ and its value forhelium gas at $0^{\circ} \mathrm{C}$ is 0.1832 and $T_{g}$ is the temperature of gas.Traditionally, control of the internal pressure is done by using airinflated bladders within the envelope, known as ballonets [7]. This concept is also both directly and indirectly applicable to HB aircrafts as well. For example, similar to airships, it can be applied to make HB aircrafts heavy by getting the air from surrounding air. Moreover, for a constant altitude condition, the weight also decreases with burning of fuel and the control surfaces may/do not compensate for the decrease in the overall lift requirement of the aircraft.

For ballonets [1], it is first required to find out the percent fullness $(\% F)$ for the additional required volume of hull. The structural anatomy of non-rigid and semi-rigid airships are not rigid enough to maintain the aerodynamic shape of the outer hull and ballonets help in maintaining the outer contour during the descent segment of flight. Ballonets are used to compress the expansion of lifting gas in gas bags; the required extra volume for which can be estimated by using Eq. (4), [1]:

$$
\% F=\frac{\rho_{H}}{\rho_{S L}}=\frac{P_{H} T_{S L}}{P_{S L} T_{H}}
$$

$P_{H}$ and $T_{H}$ are the values of atmospheric pressure and temperature, respectively at the defined height pressure. SL denotes the atmospheric conditions corresponding to sea-level or the altitude from where HB aircraft will take-off. Once the volume of lifting gas at sealevel is calculated, this value is then divided by percent fullness to get the required volume of ballonets.

\subsection{Aerodynamic Module}

In this module, aerodynamic contour of wing and hull is discussed. In order to get a first order aerodynamic response of then wing and hull of an HB aircraft, only three major parameters are required, i.e. the reference area, zero-lift drag coefficient and airfoil selection.

\subsubsection{Selection of Airfoils}

Similar to aircraft design, airfoil is the heart of aircraft and one of the major constraints for its selection is the $C_{L \max }$ ) aero required for aerodynamic lift. For this purpose, an initial estimation of $\left.C_{L \max }\right)_{\text {aero }}$ is required, which will provide guidelines for selection of airfoil maximum lift coefficient, $C_{l \max }$. As a first guess, required lift for level flight is estimated by taking $\left.L_{a e r o}\right)_{\max }$ equal to $W_{G T M}$ and similar to aircraft design one can take $\left.C_{L \max }\right)_{\text {aero }}$ equal to $0.9 C_{\text {lmax }}$. The term $W_{G T M}$ is used here to cater for the effects of mass of air in ballonets in gross takeoff weight[1]. $W_{G T M}$ is the weight corresponding to gross takeoff mass, excluding the mass of lifting gas and apparent mass

\subsubsection{Wing Sizing}

The wing is the most important component of an aircraft and low drag and high lift wing is always desirable. For a HB aircraft, the primary function of the wing is to generate sufficient aerodynamic lift to balance $W_{\text {net }}$ obtained from initial assumption of buoyancy ratio (Eq. 2). With the progress of the science of aerodynamics, now there are a number of low fidelity panel method based software like Javafoil [13], XFLR [14], etc., available for 
estimation of the lift in quite less time as compared with any CFD solver. Based on the initial sketch, the wing can be designed at conceptual level. In this way projected area of the wing can be obtained for its first order approximation. This digit can further be refined after calculating the wing loading for which complete aerodynamic analysis is required. For a HB aircraft, wing loading is defined here as $\frac{W_{\text {net }}}{S_{\text {aero }}}$. For aircrafts, wing loading is usually referred to takeoff conditions [1] and the same holds good for HB aircraft as well.

\subsubsection{Aerodynamic Contour Design for Hull}

As with any other airship and aircraft, the major contribution of drag for an HB aircraft is also due to the hull. A general expression for the hull's drag for HB aircrafts can be calculated as the sum of zero-lift drag and induced drag, which is expressed as Eq. (5):

$$
C_{D_{H}}=C_{D O_{H}}+K_{H}\left(C_{L_{H}}^{2}\right)
$$

Where, $K_{H}$ for airships and hybrid airships can be estimated by using Eq. (6). This expression is obtained from the trend plot of experimental data of body of revolution (without tail), body of revolution and hybrid (with tails), lifting bodies and of aircrafts [12]. Moreover, in this equation $A_{R}$ is defined in terms of projected planform area:

$$
K_{H}=-0.0145\left(\frac{1}{A_{R}}\right)^{4}+0.182\left(\frac{1}{A_{R}}\right)^{3}-0.514\left(\frac{1}{A_{R}}\right)^{4}+0.838\left(\frac{1}{A_{R}}\right)-0.053
$$

If the hull is aerodynamically lofted to have a shape somewhat of a cambered airfoil then it will contribute more towards induced drag and use of above mentioned relationship is still open to question. For aircrafts, induced drag of fuselage is not calculated separately as major lift is coming from the wings attached with fuselage. On the other hand, nonrigid, semi-rigid and even rigid airships were designed from hull of body of revolution and have no aerodynamic lift at zero angle of attack [15] due to symmetric shape of hull. Because standard shapes of bodies of revolution can only produce lift when it is at certain angle of attack, therefore drag due to lift exists due to the hull as lift is generated for $\alpha>0$ [12]. For aircrafts [16], empirical relationships used for the estimation of induced drag always cater for the aspect ratio of wing as it is reference lifting surface for calculation of lift and drag. Induced drag formula available in most of the references related to aircraft design [1], [3], [16-18] is based on Prantdl's lifting line theory, applicable to high aspect ratio wings; whereas the application of the same for estimating the induced drag of hull by considering the hull as low aspect ratio wing will be erroneous. The only realistic solution of this issue at the moment is to perform some numerical simulation to estimate lift as well as total drag.

Similar to a fuselage of an aircraft, zero-lift drag or parasite drag of hull consists mainly of skin friction drag, which can be calculated by considering a calculated flat-plate skin friction coefficient, $C_{f, H}$ and $F F_{H}$ form factor, that estimates the pressure drag due to viscous separation [2]. This estimation is done for major aerodynamic components of aircraft, and is given by Eq. (7):

$$
C_{D, o, H}=C_{f, H} \cdot F F_{H} \cdot \frac{S_{w e t, H}}{S_{\text {aero }}}
$$


This equation is used for calculating the drag of other components of $\mathrm{HB}$ aircraft by the build-up method. For the estimation of wetted area of hull of a $\mathrm{HB}$ aircraft there are different calculation possibilities [2],16], out of which the one suggested for airships [1] is shown as Eq. (8).

$$
S_{w e t, H}=\pi \cdot d_{H} \cdot l_{H} \cdot\left(1-\frac{2}{\lambda_{H}}\right)^{2 / 3}\left(1+\frac{1}{\lambda_{H}^{2}}\right)
$$

The form factor for estimation of drag coefficient of fuselage of aircraft Eq. (9),[2] and of hull [18]are shown below as Eq. (11) and (12) respectively. Out of them, suggested one for hull of HB aircraft is Eq. (9), but with a correction factor of 0.85 [1]:

$$
\begin{gathered}
F F_{H}=\left(1+\frac{60}{\lambda_{F}^{3}}+\frac{\lambda_{H}}{400}\right) \\
F F_{H}=\left(1+\frac{1.5}{(\lambda)^{\frac{3}{2}}}+\frac{7}{\lambda^{3}}\right) \\
F F_{H}=3 \cdot \lambda \cdot\left(1+\frac{1.5}{(\lambda)^{\frac{3}{2}}}+\frac{7}{(\lambda)^{3}}\right)
\end{gathered}
$$

It is well known that friction coefficient for turbulent flow is mainly dependent on the Reynolds number and Mach number and can be calculated by using Eq. (12) [2],16]:

$$
C_{f, \text { turbulent }}=\frac{0.455}{\left(\log _{10} R e\right)^{2.58}\left(1+0.144 M^{2}\right)^{0.65}}
$$

Finally the drag force of hull, which accounts for inviscid as well as viscous drag due to lift is expressed as Eq. (13);

$$
D_{H}=q S_{\text {aero }} \cdot\left(C_{D 0_{-} H}+K_{H} C_{L_{-} H}^{2}\right)
$$

\subsubsection{Aerodynamic Lift and Drag Coefficients}

In a reference of hybrid airship [19], the aerodynamic lift coefficient is defined similar to an airplane, Eq. (14):

$$
C_{L_{\text {aero }}}=\frac{L_{\text {aero }}}{\frac{1}{2} \rho V^{2} S_{\text {aero }}}
$$

Ina reference of hybrid airship [19], total lift coefficient isexpressed in terms of $C_{L}$ ) buoy and $\left.C_{L}\right)_{\text {buoy }}$ as Eq. (15), [19].

$$
\left.\left.C_{L}=\frac{L}{\frac{1}{2} \rho_{a} V^{2} S_{\text {aero }}}=C_{L}\right)_{\text {buoy }} R_{F}+C_{L}\right)_{\text {aero }}
$$

where, variable $R_{F}$ is defined by Eq. (16) [19]: 


$$
R_{F}=\frac{g V o l}{\frac{1}{2} V^{2} S_{\text {aero }}}
$$

It can be observed from Eq. (15) that $C_{\text {Lbuoy }}$ changes with altitude. However, if the gas cells are free to expand then $C_{\text {Lbuoy }}$ has to remain constant till pressure height. Moreover, the aerostatic as well as aerodynamic lift is non-dimensionalized by $S_{\text {aero }}$, Eq. (15). From aerodynamic point of view, if the shape is invariant then there will be no contribution of buoyant lift towards the aerodynamic lift. These relationships are not suitable for any analysis work related to HB aircraft and aerostatic lift force can be balanced with some $\%$ of gross takeoff weight; described as 'dead weight lift' [20] and its corresponding mass as 'dead mass', represented by $m_{\text {dead }}$. Also, definition of reference area is not fully explored. $S_{\text {aero }}$ for a HB aircraft can be defined as the sum of the planform projected area of hull $S_{H}$ and wing $S_{W}$, which is the area of wing outside the hull.

$$
S_{\text {aero }}=S_{W}+S_{H}
$$

Induced drag of a HB aircraft can be represented by Eq. (18) and zero lift drag or pressure drag can be estimated by using the built up method of aircraft [1].

$$
\begin{gathered}
D_{i, T O T}=K \frac{\left.\left(C_{L_{\text {aero }}}-C_{L_{\text {md }}}\right)_{\text {aero }}\right)^{2} g^{2}}{q S} \\
K=K_{W}+K_{C}+K_{H}+K_{E}
\end{gathered}
$$

In Eq. (19), ' $K$ ' is the total induced drag coefficient due to wings $K_{W}$, canards $K_{C}$ and lifting hull $K_{E}$. This term accounts for inviscid as well as viscous drag due to lift. $C_{L_{m d}}$ is $C_{L}$ for minimum $C_{D}$ and for conventional airships its value is approximately equal to zero due to low camber hull. The zero lift drag of the empennages and wing can be calculated with the same procedure as for the hull, Eq. (7). The wetted area depends on the geometrical characteristics of the empennage and is estimated by using Eq. 20[2]:

$$
S_{w e t}=2 S_{\exp }\left(1+0.25(t / c)_{r} \frac{1+\tau}{1+\lambda}\right)
$$

where, $\tau$ is equal to $(t / c)_{t} /(t / c)_{r}$ and $\lambda$ represents the taper ratio. Similarly, the wetted area of wings, ventral and canards can be found by using the above mentioned equations.

\subsubsection{Drag Polar Equation}

As the aerodynamic lift is totally generated by the lifting surface, the total drag and its coefficient is given by Eq. (21), [12]:

$$
C_{D}=C_{D O}+K\left(C_{L_{\text {aero }}}-C_{L_{m d_{\text {aero }}}}\right)^{2}
$$

Usually, airships have no or very small camber, and $C_{L_{m d} \text { aero }}$ will be equal to zero [12]. The same holds good for a HB aircraft with a low camber wing attached with the nonlifting hull. Total drag of such configurations can be represented by using Eq. (22). However, the drag polar equation for a configuration of $\mathrm{HB}$ aircraft designed using a lifting hull can be approximated by using Eq. (23) [5]: 


$$
\begin{gathered}
D=\frac{1}{2} \rho V^{2} S_{\text {aero }}\left(C_{D o}+K\left(C_{L_{\text {aero }}}-C_{L_{\text {md }} \text { aero }}\right)^{2}\right) \\
C_{D}=\left(C_{D o}\right)_{\text {less_hull }}+K\left(C_{L_{\text {aero }}}-C_{L_{\text {md }} \text { aero }}\right)^{2}+C_{D_{h}}
\end{gathered}
$$

Analytical relationships of airships and aircrafts, which were discussed above will give a starting point for the conceptual design work of HB aircrafts. Unfortunately, at present the wind tunnel testing of such aircrafts is quite rare. But like conventional aircrafts, it is perceived that the aerodynamic data obtained from wind tunnel testing can be utilized in future for the correction of existing analytical relationship like form factor, induced drag factor of hull. Unfortunately, except ESTOLAS aircraft, experimental data for estimation of aerodynamic characteristics of such unconventional aircrafts is not available. It is perceived that whenever the design methodology for different versions of $\mathrm{HB}$ aircraft, starting from a light passenger aircraft to a very high payload cargo type is available, then the existing relationships will be a starting point for the design work.

\section{CONCLUSION REMARKS}

Flying characteristics of HB aircrafts will be a merger of aircraft and airship technology due to lift augmentation, i.e. lift generated by buoyancy and due to pressure difference. Since the aerostatic lift remains constant till pressure altitude; therefore its coefficient has to remain constant. Aerostatic lift is independent of the weight, and volume is the only parameter of concern. The inflation and deflation of the ballonets depends on exact estimation of pressure height. There are no existing historical trends available for initial estimation of lift generated by an aerodynamically lofted hull. Numerical simulations will be required to get a first-hand account of the coefficient of drag. It can be perceived that the existing analytical relationships of aircraft and airship will provide a starting point to develop the design methodology of HB aircrafts.

\section{ACKNOWLEDGEMENT}

The support of the Ministry of Science, Technology and Innovation (MOSTI), Malaysia, under the grant 06-01-08-SF0189 is gratefully acknowledged.

\section{REFERENCES}

[1] Raymer D. (2012) Aircraft design: A conceptual approach, 5th Edition. American Institute of Aeronautics and Astronautics, Inc., Washington, DC.

[2] Nita M, Scholz D. (2013) From preliminary aircraft cabin design to cabin design to cabin optimisation-Part I, U.P.B. Sci. Bull., Series D, 75(3). .http://www.fzt.hawhamburg.de/pers/Scholz/OPerA/OPerA_PUB_UPB-Sci-Bull-D-75-3_13-07-01.pdf, [retrieved 4 November. 2014]

[3] Grant CE, Leland NM. (2013)Fundamentals of aircraft and airship design: volume II, Aircraft Design. American Institute of Aeronautics and Astronautics, AIAA..

[4] Lowry JG, PolhamusEC. (1957) A method for predicting lift increments due to flap deflection at low angles of attack in incompressible flow. NACA-TN-3911 1957.http://www.naca.central.cranfield.ac.uk/reports/1957/naca-tn-3911.pdf [retrieved 2 December. 2014]

[5] Haque AU, Asrar W, Omar AA, Sulaeman E, Ali JM. (2014) Conceptual design of a winged hybrid airship," in 21st AIAA Lighter-Than-Air Systems Technology Conference, AIAA2014-2710. 
[6] Ardema M, Flaig K. (1980) Parametric study of modern airship productivity. NASA TM81151.

[7] Konstantinov L. (2003) The theory of gas and airships theory. Tech. Sci. J. Mod. Aerostatic Probl., pp. 1-21. http://www.fplgenerator.free.fr/Aero/Airship, [retrieved 17 December. 2014]

[8] Khoury GA. (2012) Airship technology, vol. 10. Cambridge University Press.

[9] Burgess CP. (1927) Airship design, University Press of the Pacific, Honolulu, Hawaii.

[10] Khoury GA, Gillett JD. (1999) Airship technology. Cambridge Univ. Press, New York.

[11] FAA Regulations (2001) Regulations on airship design criteria. FAA P-8110-2.

[12] Carichner GE, Nicolai LM. (2013) Fundamentals of aircraft and airship design: volume II, Airship Design. American Institute of Aeronautics and Astronautics, AIAA.

[13] Hepperle M. (n.d.) Javafoil users guide. pp. 1-34, http://www.mh-aerotools.de, [retrieved 17 March. 2014]

[14] Deperrois CA. (2001) About stability analysis using XFLR5, http://www.xflr5.com, [Retrieved 10 Feb. 2014]

[15] Hoerner, S. F. (1965). Fluid-Dynamic Drag, Hoerner Fluid Dynamics, Bakersfield, CA. In Library of Congress Catalog Card (No. 64-19666)

[16] Roskam J. (1990) Airplane design. Kansas: Roskam Aviation and Engineering Corporation.

[17] Anderson JD. (1999) Aircraft performance and design. McGraw-Hill, Boston.

[18] Gudmundsson S. (2013) General aviation aircraft design: Applied methods and procedures. Butterworth-Heinemann.

[19] Zhang KS, Han ZH, Song BF. (2010) Flight performance analysis of hybrid airship: Revised analytical formulation.J. Aircr., 47(4):1318-1330.

[20] Prentice JT, Barry E, Beilock RE, Phillips AJ. (2005) The rebirth of airships. Transp. Res. Forum, 44(1):173-190.

[21] Gamaleyev A. (2012) ESTOLAS Project Description. http://www.estolas.eu/. [Accessed: 6 March, 2014]

\section{NOMENCLATURE}

\begin{tabular}{|c|c|c|}
\hline$A_{R}$ & $=$ & aspect ratio \\
\hline$B_{R}$ & $=$ & buoyancy ratio \\
\hline$C_{L_{\text {cruise }}}$ & $=$ & aerodynamic lift coefficient of $H B$ aircraft at the cruise condition \\
\hline$C_{L_{\text {max }} \text { aero }}$ & $=$ & maximum aerodynamic lift coefficient of $H B$ aircraft \\
\hline$C_{L_{m d}}$ & $=$ & coefficient of aerodynamic lift of HBaircraft for the minimum drag \\
\hline$\left(C_{D_{0}}\right)_{\text {less_hull }}$ & $=$ & zero-lift drag coefficient HBaircraft, less of the hull \\
\hline$C_{D_{O}}$ & $=$ & zero-lift drag coefficient of hybrid buoyant aircraft \\
\hline$C_{D_{\min }}$ & $=$ & coefficient of minimum drag of HBaircraft \\
\hline$H B$ & $=$ & hybrid buoyant \\
\hline$K$ & $=$ & drag due to lift factor \\
\hline$L_{\text {buoy }}$ & $=$ & aerostatic lift, $(N)$ \\
\hline$\left.L_{\text {aero }}\right)_{\max }$ & $=$ & maximum aerodynamic lift, $(N)$ \\
\hline$m_{G T M}$ & $=$ & total mass corresponding to gross takeoff mass, $(\mathrm{kg})$ \\
\hline$q$ & $=$ & dynamic pressure, $\left(\mathrm{N} / \mathrm{m}^{2}\right)$ \\
\hline$R$ & $=$ & universal gas constant, $(\mathrm{J} / \mathrm{mol} . \mathrm{K})$ \\
\hline$S_{r e f}$ & $=$ & reference area, $\left(\mathrm{m}^{2}\right)$ \\
\hline$S_{w e t, H}$ & $=$ & wetted area of hull, $\left(\mathrm{m}^{2}\right)$ \\
\hline Vol & $=$ & volume, $\left(m^{3}\right)$ \\
\hline
\end{tabular}


IIUM Engineering Journal, Vol. 16, No. 1, 2015

$\begin{array}{lll}V & = & \text { velocity, }(\mathrm{m} / \mathrm{sec}) \\ \rho & = & \text { density, }\left(\mathrm{kg} / \mathrm{m}^{3}\right) \\ \lambda_{H} & = & \text { finenss ratio of hull } \\ \mathrm{a} & = & \text { air }\end{array}$

